\title{
Corporate Social Responsibility and Executive Compensation: The Negative Externality Perspective
}

\author{
Ahmed Marhfor $^{1, *}$, Kais Bouslah ${ }^{2}$, M'Zali Bouchra $^{3}$ \\ ${ }^{1}$ Université du Québec en Abitibi-Témiscamingue \\ ${ }^{2}$ University of St. Andrews \\ ${ }^{3}$ Université du Québec à Montréal
}

\section{ARTICLE INFO}

\section{Article history:}

Received 03 December 2019

Revised 17 February 2020

Accepted 03 March 2020

Published 31 March 2020

\section{Keywords:}

Corporate social responsibility

CEO compensation

Negative externality

Market failure

Stakeholder`s management

Public interest theory

\begin{abstract}
This research develops a new argument that departs from traditional theories that explain the potential impact of Corporate Social Responsibility (CSR) on Chiefs Executive Officers (CEOs) compensation. More specifically, we argue that if CSR investments provide value for firm's shareholders and stakeholders, they can also decrease firm's competitors' value (negative externality hypothesis). As a result, inefficient CEO compensation may arise even if CSR choice allows managers to act in the best interest of firm's shareholders and non-investing stakeholders. In sum, our new perspective indicates that excessive levels of CEO compensation are more than a principal-agent-stakeholder problem. In addition, our new theoretical argument suggests that voluntarily CSR should not be a relevant factor for achieving efficient levels of CEO compensation.
\end{abstract}

\section{Introduction}

Over the last decades, one particular subject that has attracted much attention and criticism is CEO compensation. This issue has raised both ethical and economic concerns by shareholders, workers, communities, academics and regulators. In the literature, many scholars consider CEOs to be overpaid from an economic perspective (Bebchuk \& Fried, 2003; Bertrand \& Mullainathan, 2001). They argue that excessive CEO compensation is the result of powerful managers that determine their own pay levels and extract rents from poorly governed firms (managerial power theory). According to these authors, many features of executive compensation reflect managerial rent-seeking rather than the provision of efficient incentives. The managerial power approach suggests that compensation packages depart from value-maximizing outcomes in directions favorable to managers. On other hand, a different strand of research has examined whether socially responsible firms recognize the potential problems that come with excessive levels of CEO pay and thus propose more efficient pay packages and structures in comparison to firms with weak CSR commitments. In the debate about the impact of CSR on CEO compensation, two prominent theories have been proposed to explain either a negative association (CSR as a mean to resolve conflicts among stakeholders) or a positive association (CSR as an agency problem). For instance, based on the stakeholders' theory, Cai et al. (2011) argue that CEOs who practice stakeholders' management should be more inclined to resolve conflicts of interests among stakeholders. Therefore, to mitigate such conflicts (e.g. the widening pay gap between executives and average workers), managers of firms with strong CSR engagement will accept a more modest pay in comparison to managers of firms with weak CSR engagement. Furthermore, according to Cai et al. (2011) and Saphira et al. (2014),

* Corresponding author.

E-Mail address: ahmed.marhfor@uqat.ca 
stakeholders' management should also lower firm's risk (e.g. less labor strikes, less litigation risk....) and create a moral capital that will act like an insurance policy. As a result, the risk-decreasing effect of CSR should not justify high CEO compensation.

In this paper, we propose a new theory (negative externality hypothesis) that explains why excessive CEO compensation may still arise even if CSR engagement maximizes shareholders and stakeholders value. More specifically, we consider two kind of independent entities: 1) firms that move beyond legal requirements to satisfy the needs of non-investing stakeholders and maximize shareholders' value, 2) firms that place greater emphasis on value maximization but consider CSR investments as a waste of valuable resources. We posit that the relationship between CSR and CEO pay depends on whether CSR investments are value increasing or value decreasing for the firm, its stakeholders' and also for its competitors. To date, the literature focuses only on whether CSR engagement is value increasing or decreasing for the firm and its stakeholders' without taking into consideration its potential impact on firm's competitors. In this respect, the stakeholders' management of talented CEOs can increase organizational effectiveness, improve customers' loyalty, allow higher access to valuable resources (e.g. top quality employees), and create a distinctive competitive advantage for the firm that will impact negatively its competitors. Hence, firms' with high CSR standards may impose a negative externality on firms' with low CSR standards (interfirms costs). To internalize the negative externality, firms' with poor CSR standards can offer highly generous compensation packages to attract managers with exceptional stakeholders' management skills. It is worth mentioning that even if disrupted firms can replicate CSR initiatives of the innovative firm, they may still need the talent and knowledge of the its CEO to achieve efficiency. Therefore, if we combine the negative externality that talented CEOs impose on competitors with the assumption that CEOs talent is movable and firms are competing for managerial talent, we can witness an upward trend in CEO compensation. Our theoretical framework suggests that CEO pay should include both private costs (the optimal salary paid by the firm to its CEO based on its contribution to firm wealth creation) and external costs (a fraction of market cap losses of firm's competitors). With the negative externality, we should have a private level of CEO compensation that is higher than a social optimal level of CEO compensation (the salary paid based on the CEO contribution to wealth creation). Consequently, we should witness a market failure in CEO labor markets even in the absence of the principal-agent-stakeholder problem.

Our new perspective sheds a different light on the potential association between CSR and CEO pay. It suggests that effective CSR should result in excessive CEO compensation. In fact, we argue that when voluntarily CSR initiatives are at optimal levels for some firms, we should witness a failure in CEO labor markets. Therefore, based on the negative externality hypothesis, CSR should be irrelevant for helping firms achieve optimal levels of CEO compensation. We also conjecture that it is possible to have a neutral effect of CSR on CEO pay when policymakers work for the public good. Indeed, the presence of a market failure may justify regulatory solutions. If regulators promote the public interest (public interest theory) and propose efficient regulations that correct market failures (e.g. negative externalities linked to CSR initiatives), CSR should have no impact on CEO compensation. This is possible because our theoretical framework indicates that the main source of a positive association between CSR and CEO pay is the negative externality that talented CEOs impose on other firms (firms with weak and inefficient CSR engagement). In this respect, if policymakers are able to set regulations that promote strong CSR engagements for all firms, it should be possible to internalize the negative externality described in this research. As a result, CSR should be irrelevant to CEO pay issue. To the best of our knowledge, our work is the first study that departs from the two prominent theories in the CSR-executive pay literature to shed a different light on the potential association between the two concepts. It is also the first analysis that describes, explains and predicts the null hypothesis (absence of CSR impact on CEO compensation). We argue that a neutral association is possible when CSR investments are at optimal levels for all firms because regulators work for the public good. In this case, any competitive advantage should be explained by other factors besides CSR engagements.

This work also develops the argument that the potential link between the two concepts depends not only on the level of CSR but also on the ability of the firm to deliver consistent social performance. We then introduce a novel concept (CSR consistency/inconsistency) to the literature that examines CSR-executive pay relationship. Following many authors (e.g. Wang \& Choi, 2013), we argue that the level of CSR can vary over-time (temporal inconsistency) and across stakeholders (inter-domain inconsistency). Low variability should send a positive signal to stakeholders and the market about the reliability of firm's social engagement. On the other hand, high variability can lead to doubts about firm's CSR commitment and indicate that managers engage mostly in short-termism (Wang \& Choi, 2013). Hence, we argue that it is important to consider both dimensions (the level of CSR and the degree of consistency in CSR). Focusing only on the level of CSR may not give a complete picture of the relationship between CSR and CEO pay. For instance, if CSR engagement creates value for firm's stakeholders, the latter may consider a combination between high level of CSR and low consistency in CSR to be equivalent to a combination between low level of CSR 
and low consistency in CSR. Consequently, it is relevant to explore the role of consistency (temporal and interdomain) and examine its interaction with the level of CSR in influencing CEO compensation. To the best of our knowledge, this research is the first empirical analysis that introduces this new construct to the CSR-CEO pay literature. The remainder of the paper is organized as follows. Section 2 reviews prior literature. In sections 3, we explain the rationales behind our new perspective. Section 4 describes the data and our empirical research design. Section 5 presents our empirical findings. Section 6 concludes.

\section{Literature Review}

The literature on CEO pay is mainly based on the principal-agent problem. It proposes two different views on how managers' compensation and the agency problem are linked. The first view (optimal contracting theory) considers CEO pay as a solution to the principal-agent problem. This approach recognizes that managers do not automatically seek to maximize shareholders value. Therefore, pay arrangements should be designed to provide managers with efficient incentives (Jensen \& Murphy, 1990; Murhy, 1999). The purpose of these incentives is to align CEOs' interests with shareholders interests (share-value maximization). According to the optimal contracting approach, high levels of CEOs compensation are simply a reflection of their skills and their successful strategies (Shorter \& Labonte, 2007; Faria et al. 2014; Aaron et al. 2015). Hence, high compensation only reflects the high managerial productivity of the CEO. On the other hand, a second approach (managerial power theory) suggests that CEO compensation packages depart from value-maximizing outcomes in directions favorable to managers. Advocates of the managerial power theory (Bebchuk \& Fried, 2003) argue that boards (for many reasons) do not negotiate compensation packages that are in the best interests of shareholders and that CEO labor market is not functioning efficiently. Hence, a policy response is justified to correct the misallocation of resources. To date however, we are not aware of any study suggesting that inefficient compensations can still arise even if CEOs maximize shareholders value.

The CSR literature proposes mainly two theories regarding CSR choice and CEO pay. First, the stakeholders' theory considers CSR as a process that helps mitigate conflicts of interest between insiders, shareholders and noninvesting stakeholders (Jensen 2002; Harjoto \& Jo, 2011; Jo \& Harjoto, 2012). This conflict-resolution hypothesis suggests that managers use CSR to resolve conflicts among stakeholders and act in the best interests of their shareholders. Indeed, serving the interests of other non-investing shareholders should help firms build good relationships with them and gain their support and cooperation, which will enhance firm's financial performance and shareholders wealth (Wang \& Choi, 2013). For instance, some customers may increase their demand and accept to pay high prices because they feel more attached to firms' who care about their workers, the environment and communities (Wang \& Choi, 2013). Employees may also have greater satisfaction, motivation, indentify more strongly with the firm, and accept to contribute more to it success when the CEO-employee pay gap is reasonable (Wang \& Choi, 2013). On the other hand, excessive CEO pay may result in less motivated and more cynical employees. This can lead to lower productivity and frequent labor strikes, which will impact negatively firm's financial performance. Hence, to reduce potential conflicts with workers and other stakeholders, CEOs who care about building better managers-stakeholders relationships will pay attention to the gap between their pay and average worker pay. We would, therefore, expect an inverse association between CSR engagement and CEO compensation under the stakeholders' theory. One can argue that building valuable relationships with firm's stakeholders represents an important source of firm's competitive advantage. The latter may impact positively financial performance and represent an argument for providing incentives to CEOs (high compensation based on the optimal contracting approach). This would suggest a positive association between CSR and CEO pay. However, by lowering conflicts of interests between managers and stakeholders, CSR engagement should also lower firm risk. This risk-decreasing effect should not justify any increase in CEO pay. It may even result in a lower compensation.

Second, the agency theory views CSR engagement as a managerial rent-seeking behavior (e.g. Barnea \& Rubin, 2010; Cespa \& Cestone, 2007). Here CSR takes place at the expense of shareholders, other stakeholders and the society. In other words, CSR investments are inefficient because they profit only to managers. For instance, CSR choice may allow managers to build reputation as good citizens (Barnea \& Rubin, 2010). To the extent that a good reputation improves CEO bargaining power and employment opportunities, a CEO will be able to negotiate more easily higher levels of compensation. Hence, we should expect a positive association between CSR commitment and CEO pay under the agency theory. In the same line of reasoning, Cespa and Cestone (2007) argue that poorly performing CEOs have an interest in engaging in CSR because such engagement generates support from some shareholders and stakeholders activists. Ultimately, this support should reduce the probability of CEOs turnover. Here, managers develop entrenchment strategies to protect their jobs. In fact, building "coalitions" with other stakeholders may improve the protection and the bargaining power of CEOs when dealing with unsatisfied 
shareholders and boards. It will also lower the ability of the board to identify and terminate poorly performing CEOs. Consequently, the greater the protection and the bargaining power of the CEO, the greater will be its compensation.

\section{CSR, CEO Pay and the Negative Externality Perspective}

Theoretically, it is extremely difficult to determine whether top managers pay is excessive because CEOs marginal product (CEOs wealth creation) is not directly observed. The managerial power theory suggests that the principalagent problem represents a governance/market failure that could lead to CEOs being paid inefficiently. Hence, regulators should propose laws that improve corporate governance (e.g. more independent boards...). In addition, firms can also choose arrangements beyond what is legally required (e.g. CSR engagements) to find efficient solutions to CEO pay issue. In this project, we propose a new theory that suggests the prevalence of a market failure even in the absence of the principal-agent-stakeholder problem. In particular, even if boards are sufficiently independent of managerial influence, have precise information about CEO marginal product and managers use CSR to maximize shareholders and stakeholders value; we suggest that a negative externality exists through executives' strong skills and talent. The presence of this externality should lead to a market failure. Externalities are positive/negative effects for third parties outside the market interactions between the buyer and seller (e.g. CEOs and Boards). Classical examples of externalities are pollution and information production (disclosure by public firms). For instance, firm's voluntarily disclosure involves externalities because the information provided by the disclosing party can benefit other market participants and put the firm at a disadvantage relative to its competitors, suppliers, etc... Hence, for each issuer, information disclosure involves two different kinds of costs: operational costs and interfirm costs (Fox, 1999). Operational costs are expenses that an issuer incurs to provide information. As stressed by Fox (1999), these costs are costs both to the issuer and society. On the other hand, interfirm costs are costs only to the issuer because they put him at a disadvantage relative to competitors, suppliers and customers. Hence, given the fact that firms endure all costs of voluntarily disclosure but cannot obtain all of its value, firms will choose to disclose significantly less than is socially optimal (Easterbrook \& Fischel, 1984). Information externalities should then lead to a market failure (Easterbrook \& Fischel, 1984). The latter may justify government intervention because an efficient mandatory disclosure regime substantially limits firm's ability to disclose less (Easterbrook \& Fischel, 1984). In the same line of reasoning, voluntarily CSR initiatives can lead to inter-firm costs (negative externalities). In this respect, when managers will voluntarily serve the interests of firm stakeholders', they may build good relationships with powerful stakeholders, use critical resources that some stakeholders may provide to increase organizational effectiveness, and create a sustained competitive advantage that will affect negatively their competitors. Hence, strong CSR engagement can create substantial benefits for the firm but can also impacts negatively the market value of firms with weak CSR engagement. In this paper, we argue that CEO pay of firms' with strong CSR initiatives should involve CEO wealth creation and a fraction of market cap losses of competitors. As a result, the principal-agent-stakeholder problem should not be the only perspective that can explain inefficient CEO labor markets.

Some assumptions are fundamental to our theoretical framework. First, we assume that boards are well informed and act in the best interests of shareholders (absence of the principal-agent problem). Second, we assume that board members know the marginal product of CEO efforts and talent. Third, we assume that firms are competing for managerial talent. Fourth, some CEOs have exceptional talent in comparison to others and their talent is movable and rare. Fifth, talented CEOs move beyond legal requirements to satisfy the need of non-investing stakeholders (absence of the principal-agent-stakeholder problem). In addition, the stakeholders' management of talented CEOs increases organizational effectiveness and creates a distinctive competitive advantage for the firm. As suggested by Barney (2018), a stakeholder approach to the resource-based theory can allow managers to have access to critical resources that many stakeholders can provide. A talented CEO that can assemble in efficient ways the critical resources that some stakeholders provide with other resources in the firm will generate more economic profits than its competitors and create a sustained competitive advantage (Stakeholder Resource-based theory). Based on these assumptions, we argue that CEOs with exceptional talent can create disruptive business models (e.g. Apple, Amazon, Netflix etc...) that have distinctive competitive value for their companies but will impact negatively their competitors. For instance, Amazon is capable of erasing billions of dollars of other competitors' capitalisation simply by announcing that it's entering their industry (Markets Insider, 2017). Hence, some CEOs exceptional talent can have negative effects on other competitors and industries. Because of the negative externality that "superstar" CEOs impose on other firms, it is possible that shareholders'/boards of companies that are threatened by these "superstars" try to hire them in order to profit from their exceptional talent. If highly talented CEOs are paid as much as the revenue they contribute to their firms (optimal contracting theory), a disrupted company need to pay them more so it can attract their skills. Otherwise, talented CEOs will not accept the disrupted company job offer. It is also possible that another disrupted 
company will bid higher than the first one and we can witness an upward trend in pay that can result in inefficient labor markets. One driver of such scenarios is the CEO option to work for other competitors. There is also the possibility that the disruptor firm will willingly accept to offer its "superstar" CEO an excessive pay from an economic perspective in order to retain his-her talent. Therefore, because skilled managers that pursue efficient shareholders' management initiatives capture so much of the market, we should witness large and inefficient compensation packages for CEOs who practice effective stakeholders' management. Finally, even if disrupted firms can replicate the business model of the innovative firm, they may still need the talent and knowledge of the "superstar" CEO to achieve efficiency. In sum, our theoretical model indicates that CEO compensation includes both private costs (CEO marginal product) and external costs (a fraction of market cap losses of competitors). With the negative externality (external costs) explained above, the company private marginal costs should exceed the social marginal costs. This is socially inefficient. As a consequence, we should witness a market failure in CEO labor markets even in the absence of the principal-agent-stakeholder problem. Our new perspective suggests that it is possible to have a positive association between CEO pay and CSR when CSR engagement is at optimal levels for some firms. Hence, we depart from previous studies (e.g Cai et al. 2011) that consider a negative association between CSR and CEO pay to be consistent with the stakeholders' theory. Furthermore, it is worth mentioning that the main source of the positive relationship is the negative externality that talented CEOs impose on other firms. This view is completely different from the argument that suggests that managerial rent-seeking behavior is the main source of a positive relationship between CEO pay and CSR (overinvestment argument based on the agency theory). Indeed, under the negative externality hypothesis, managers who pursue inefficient stakeholders-related initiatives should have lower compensations because of the negative externality that skilled managers' impose on their firms. The above arguments lead to the following hypothesis:

Hypothesis 1: When CSR investments are at optimal levels for some firms, we should expect a positive association between CSR engagement and CEO pay

In the literature, some scholars argue that government regulation is the best way to achieve efficiency when a market failure is indentified (Posner, 1974). In this respect, we argue that when regulators have relevant information and enforcement power to efficiently correct market failures (e.g. inefficient CSR levels that my result in inter-firm costs), we should expect market-level mechanisms (e.g. CSR engagement) to have a neutral impact on CEO pay. Murphy (2013) suggests that any explanation for CEO compensation that ignores political factors is critically incomplete. The reason government regulation can add a new dimension into CEO compensation is because the interests of regulators differ significantly from CEOs, shareholders and other stakeholders' interests (Murphy, 2013). In this respect, when policymakers are able to set regulations that will help internalize the negative externality proposed in this research and allow CEO compensation to reflect only CEO marginal product (instead of CEO marginal product and inter-firms costs), CSR engagement should be irrelevant to CEO pay. In fact, to be effective, CSR engagement should have a neutral impact on executive compensation because existing regulations already allow the best possible allocation of firm's scare resources (CEO pay that includes only efficient levels of private costs). Hence, the absence of a relationship between CSR and CEO pay could be an indicator of high economic and social welfare. We should then expect the following:

Hypothesis 2: When regulators work for the public good and CSR investments are at optimal levels, we should expect a neutral association between CSR engagement and CEO pay

On the other hand, the private interest theory (capture theory) suggests that regulations are not enacted for the public good (Posner, 1974; Brown, 1996). This theory assumes that legislators serve only the special interests of some groups because the political process is plagued by politicians' self-interest and special interest groups. Under the private interest theory, regulators should not be able to set legislations that allow the best possible allocation of resources and help internalize the negative externality of CSR investments. As a result, we should expect a positive association between CSR and CEO pay when some managers pursue effective stakeholders-related initiatives and regulators do not work for the public good. In summary, we can propose the following:

Hypothesis 3: When regulators do not work for the public good and CSR investments are at optimal levels for some firms, we should expect a positive association between CSR engagement and CEO pay 
We also develop the argument that the potential link between CSR and CEO pay depends not only on the level of CSR but also on the ability of the firm to deliver consistent social performance. Following many authors (e.g. Wang \& Choi, 2013), we argue that the level of CSR can vary over-time (temporal inconsistency) and across stakeholders (inter-domain inconsistency). Low variability should send a positive signal to shareholders and stakeholders about the reliability of firm's social engagement. At the same time, it should also send a negative signal to firm's competitors. Indeed, the ability of managers to deliver consistent social performance (temporal and inter-domain) may strengthen the negative externality that their actions impose on firms with weak CSR engagements. Therefore, high CSR consistency (temporal and inter-domain) should strengthen the positive association between CSR and CEO pay:

Hypothesis 3a: Maintaining high consistency in CSR should strengthen the positive association between CSR engagement and CEO pay

On the other hand, high variability (low consistency) in CSR can lead to doubts about firm's social engagement and indicates that managers engage mostly in short-termism (Wang \& Choi, 2013). This may be good news for firm's competitors because low consistency in CSR will harm managers' reputation and cause outrage among stakeholders who may change their behavior and withdraw their "endorsement" and "support" to managers. Hence, low CSR consistency can undermine managers' power and reduce their ability to have access to critical resources that stakeholders can provide in order to create distinctive and sustained competitive advantage (stakeholder resourcebased theory). The above arguments indicate that low consistency in social performance can weaken the positive association between CEO pay and CSR.

Hypothesis 3b: Maintaining low consistency in CSR should weaken the positive association between CSR engagement and CEO pay

As suggested earlier, our analysis departs from previous studies (e.g. Cai et al. 2011) that consider a negative relationship between CSR and CEO pay to be consistent with the conflict resolution hypothesis. In fact, to expect a negative association between CSR and CEO pay, scholars should focus on the virtue or moral character of CEOs rather than on the consequences of their actions (e.g. conflicts resolution). Virtue ethics suggests that CSR engagement is not strategic or stakeholder driven. In this respect, Saphira et al. (2014) argue that altruistic CEOs who engage in CSR for intrinsic reasons will be prepared to trade off some of their pay for the satisfaction derived from managing a socially responsible firm. As suggested by Cai et al. (2011) and Saphira et al. (2014), virtue ethics could explain why a lower compensation is more desirable for CEOs with high moral standards and high managerial talent. Therefore, to the extent that virtue ethics characterises CEOs motivation, we can propose the following hypothesis:

Hypothesis 4: If CEOs engage in CSR for intrinsic motivations (virtue ethics), we should expect a negative association between CSR engagement and CEO pay

\section{Research Design and Data}

To explore the role of CSR and consistency in CSR in influencing CEO pay, we will run variants of the following regression:

$\log ($ CEO-Payi,t $)=\beta 0+\beta 1$ CSRi,t-1 $+\beta 2$ CONSi,t-1 $+\beta 3$ CSRi,t-1* CONSi,t-1 $+\Theta$ controls $+\varepsilon i, t$

CEO pay data (our dependant variable) is extracted from ExecuComp Database over the period 1992-2012. Our study regroups quantitative information on 1752 US firms and considers many aspects of CEO compensation (based pay, bonus, options grants etc...). A description of our measures of CEO compensation is given in Table (1). To proxy for CSR performance (our main independent variable), we use social data for US firms from MSCI ESG STATS (formerly KLD Research \& Analytics, Inc.). CSR is assessed based on 5 dimensions (community, diversity, employee relation, environment and product). Each dimension involves a number of strengths and concerns. Our main proxy of CSR is the number of all strength items minus the number of all concerns items for each dimension (disaggregated measures of firm's social performance (SP)). We also calculate an overall CSR score as an average of the 5 dimensions scores (aggregated measure of SP). High CSR scores indicate strong CSR engagement. For robustness, we also compute an arithmetic average for strength items (equation 2) and concerns items (equation3) 
separately. Based on equation (2) and (3), high STR (strengths) scores suggest high CSR commitment while high CON (concerns) scores indicate weak CSR engagement:

$$
\begin{aligned}
& \operatorname{STR}_{i, t}=\frac{1}{D} \sum_{d=1}^{D}\left(\frac{1}{N_{\text {STR }}} \sum_{j=1}^{J} \text { strenght }_{j}\right) \\
& \operatorname{CON}_{i, t}=\frac{1}{D} \sum_{d=1}^{D}\left(\frac{1}{N_{\text {CON }}} \sum_{k=1}^{K} \text { concern }_{k}\right)
\end{aligned}
$$

Where $d$ refers to a qualitative dimension and $\mathrm{D}$ is the total number of dimensions for firm i during year t. $\mathrm{N}_{\text {STR }}$ and $\mathrm{N}_{\mathrm{CON}}$ represent the maximum possible number of strengths and concerns for a given dimension. $\mathrm{J}$ and $\mathrm{K}$ refer to the number of strengths and concerns, respectively, within a given dimension for firm i during year $t$. These additional tests do not alter our main findings. CONS is our proxy for CSR consistency (our second explanatory variable). We propose two measures of CONS. First, inter-domain consistency is measured as the variance (standard deviation) in the level of CSR for the 5 dimensions. A low standard deviation indicates high CSR consistency. In our tests, we use the inverse of the standard deviation as a proxy for CONS. Second, we use temporal consistency. In this respect, variation in the sample mean of CSR performance over time would be one measure. However, variation over time would be a poor statistic for estimating temporal trends because firms that have improved CSR scores over time will appear to have an inconsistent CSR. Hence, we follow Wang and Choi (2010) and regress the latest five years of CSR scores in each dimension (including the data year) against time (e.g. $2000 ; 2001 ; 2002 ; 2003 ; 2004)$ to obtain the regression coefficients (5 coefficients (the slopes) and their standard error). The standard error will be a proxy for CSR temporal consistency (the lower the standard error of the regression coefficient, the greater the temporal CONS). Furthermore, an overall temporal CONS for each firm is calculated by taking the average of the temporal CONS for the 5 dimensions. Here again, we will take the inverse of the standard error as a final measure for CSR consistency. We also include into equation (1) a variety of explanatory variables that control for additional factors that determines CEO compensation (e.g. firm size, leverage, growth, financial performance, CEO age, CEO tenure, industry dummies...etc). Table (1) summarizes the measurement of variables of equation (1).

\begin{tabular}{|c|c|}
\hline Variable & Variable measurement \\
\hline Total compensation & $\begin{array}{l}\text { Base salary }+ \text { bonus }+ \text { other annual pay }+ \text { the total value of restricted stocks granted that } \\
\text { year }+ \text { the Black } \& \text { Scholes value of stock options granted that year }+ \text { long-term incentives } \\
\text { payouts }+ \text { all other total compensation. }\end{array}$ \\
\hline Cash compensation & Base salary + bonus \\
\hline CSR & $\begin{array}{l}\text { Number of all strength items - number of all concerns items } \\
\text { We have the overall score and scores of } 5 \text { subcategories (community, environment, } \\
\text { diversity, employee relations and product) } \\
\text { Overall score = average of } 5 \text { subcategories scores }\end{array}$ \\
\hline Temporal CONS & $\begin{array}{l}\text { CSR score ( } 5 \text { years })=\alpha+\beta \text { time } \\
\text { Standard error }(\mathrm{SE}) \text { of } \beta \text { is the proxy for temporal CONS. The lower the SE the higher the } \\
\text { CONS. }\end{array}$ \\
\hline Interdomain CONS & variance (standard deviation) in CSR scores for the 5 dimensions \\
\hline Size & Book value of total assets \\
\hline Leverage & Book value of debt/book value of assets \\
\hline Market-to-Book ratio & Market value of assets/Book value of assets \\
\hline
\end{tabular}

Table 1. Variables definition and measurement 


\begin{tabular}{ll}
\hline Variable & Variable measurement \\
\hline ROA & Operating income before depreciation/Book value of total assets \\
Capital expenditures & $\begin{array}{l}\text { Investment in plant and equipment during period }(\mathrm{t}) \text { divided by firm total assets during } \\
\text { period }(\mathrm{t}-1)\end{array}$ \\
Volatility & Stock return volatility in the past 5 years \\
CEO tenure & Tenure of CEO in the fiscal year (years in office) \\
CEO age & Age of CEO in the fiscal year
\end{tabular}

Hypothesis (1) and (3) predict a positive coefficient on CSR $\left(\beta_{1}>0\right)$. A neutral $\beta_{1}$ is consistent with hypothesis 2 and a negative $\beta_{1}$ is consistent with hypothesis 4 . Furthermore, hypothesis ( $3 a$ ) predicts that $\beta_{2}$ and $\beta_{3}$ (the coefficient of the interaction between CSR performance and CSR consistency) will be both positive while hypothesis (3b) suggests that $\beta_{2}$ should positive and $\beta_{3}$ should be negative. To address concerns about potential autocorrelations and unobserved heterogeneity in the data, we use a variety of estimation techniques for panel data analysis. First, to choose between fixed and random effects estimation, we use the Hausman test. The latter rejects the null hypothesis in favor of the fixed effects model. However, to further test the robustness of our results, we also use a random effects model. We also include year dummies in some specifications to control for time fixed effects. Furthermore, standards errors are adjusted for heteroskedasticity and clustering at the firm level (Petersen, 2009). Finally, we propose to conduct an endogeneity correction procedure. We rely on the instrumental variables (IV) methodology to address the fact that CSR engagement can be endogenously determined. Following Cai et al. (2011) and Saphira et al. (2014), we rely on the industry median of CSR as an instrument.

\section{Empirical results}

Table (2) presents the results of variant estimations of equation (1) using cash compensation, total compensation and aggregate measures of CSR and CSR temporal consistency (the average CSR scores and average temporal CONS for the 5 dimensions). 
Table 2.

\begin{tabular}{|c|c|c|c|c|c|c|}
\hline \multirow{2}{*}{$\begin{array}{l}\text { CSR and Temporal CONS } \\
\text { VARIABLES }\end{array}$} & \multicolumn{2}{|c|}{ OLS } & \multicolumn{2}{|c|}{ Fixed effects } & \multicolumn{2}{|c|}{ Random effects } \\
\hline & cashcomp & totcomp & cashcomp & totcomp & cashcomp & totcomp \\
\hline $\operatorname{lagCSR}$ & $\begin{array}{c}-0.4884 * * \\
(-2.53)\end{array}$ & $\begin{array}{c}-0.4879 * \\
(-1.84)\end{array}$ & $\begin{array}{l}-0.1248 \\
(-0.76)\end{array}$ & $\begin{array}{l}-0.0416 \\
(-0.20)\end{array}$ & $\begin{array}{l}-0.2305 \\
(-1.56)\end{array}$ & $\begin{array}{l}-0.1393 \\
(-0.73)\end{array}$ \\
\hline LagTP-CONS & $\begin{array}{c}0.6718 \\
(0.77)\end{array}$ & $\begin{array}{c}0.9256 \\
(0.72)\end{array}$ & $\begin{array}{c}0.6715 \\
(0.74)\end{array}$ & $\begin{array}{l}1.4265 \\
(1.20)\end{array}$ & $\begin{array}{c}1.2499 \\
(1.53)\end{array}$ & $\begin{array}{c}1.9906 * \\
(1.80)\end{array}$ \\
\hline Lag CSR * TP-CONS & $\begin{array}{l}6.9128 \\
(1.44)\end{array}$ & $\begin{array}{c}6.0472 \\
(0.95)\end{array}$ & $\begin{array}{l}-2.3467 \\
(-0.61)\end{array}$ & $\begin{array}{l}-5.4847 \\
(-1.14)\end{array}$ & $\begin{array}{l}-0.0157 \\
(-0.00)\end{array}$ & $\begin{array}{l}-2.6065 \\
(-0.56)\end{array}$ \\
\hline Lag-tenure_cum & $\begin{array}{c}0.0006 \\
(0.16)\end{array}$ & $\begin{array}{l}-0.0013 \\
(-0.32)\end{array}$ & $\begin{array}{c}0.0060^{*} \\
(1.88)\end{array}$ & $\begin{array}{c}0.0064 \\
(1.55)\end{array}$ & $\begin{array}{c}0.0028 \\
(1.09)\end{array}$ & $\begin{array}{c}0.0028 \\
(0.81)\end{array}$ \\
\hline Lag-age & $\begin{array}{l}0.0055^{* * *} * \\
\quad(2.63)\end{array}$ & $\begin{array}{l}-0.0001 \\
(-0.07)\end{array}$ & $\begin{array}{l}-0.0001 \\
(-0.06)\end{array}$ & $\begin{array}{l}-0.0011 \\
(-0.47)\end{array}$ & $\begin{array}{c}0.0027 \\
(1.43)\end{array}$ & $\begin{array}{l}-0.0005 \\
(-0.27)\end{array}$ \\
\hline Lagsizew & $\begin{array}{l}0.2234 * * * \\
(17.57)\end{array}$ & $\begin{array}{c}0.4517 * * * \\
(25.36)\end{array}$ & $\begin{array}{c}0.0413 \\
(1.50)\end{array}$ & $\begin{array}{c}0.2045 * * * \\
(4.65)\end{array}$ & $\begin{array}{c}0.1907 * * * \\
(16.99)\end{array}$ & $\begin{array}{c}0.4173 * * * \\
(26.23)\end{array}$ \\
\hline lagbleveragew & $\begin{array}{c}0.0582 \\
(1.45)\end{array}$ & $\begin{array}{c}0.0072 \\
(0.14)\end{array}$ & $\begin{array}{c}-0.0890 * * \\
(-2.06)\end{array}$ & $\begin{array}{c}-0.1336 * * * \\
(-2.65)\end{array}$ & $\begin{array}{c}0.0208 \\
(0.61)\end{array}$ & $\begin{array}{c}-0.0156 \\
(-0.39)\end{array}$ \\
\hline $\operatorname{lagRDw}$ & $\begin{array}{l}-0.1043 \\
(-0.28)\end{array}$ & $\begin{array}{c}1.1487^{* *} \\
(2.28)\end{array}$ & $\begin{array}{l}-0.0075 \\
(-0.01)\end{array}$ & $\begin{array}{c}-0.0556 \\
(-0.09)\end{array}$ & $\begin{array}{c}-0.4418^{*} \\
(-1.69)\end{array}$ & $\begin{array}{c}0.6309 * \\
(1.86)\end{array}$ \\
\hline Lagcapexw & $\begin{array}{l}-0.3620 \\
(-1.47)\end{array}$ & $\begin{array}{c}-0.4748 \\
(-1.58)\end{array}$ & $\begin{array}{c}-0.7060 * * * \\
(-2.92)\end{array}$ & $\begin{array}{c}-0.6811 * * \\
(-2.23)\end{array}$ & $\begin{array}{c}-0.4307 * * \\
(-2.27)\end{array}$ & $\begin{array}{c}-0.5483 * * \\
(-2.24)\end{array}$ \\
\hline lagROAw & $\begin{array}{l}0.5417 * * * \\
\quad(2.71)\end{array}$ & $\begin{array}{c}0.3949 * \\
(1.70)\end{array}$ & $\begin{array}{c}0.3384 * * \\
(2.13)\end{array}$ & $\begin{array}{c}0.1200 \\
(0.57)\end{array}$ & $\begin{array}{c}0.4372 * * * \\
\quad(3.19)\end{array}$ & $\begin{array}{c}0.1718 \\
(0.97)\end{array}$ \\
\hline lags_cashw & $\begin{array}{c}0.0958 \\
(0.57)\end{array}$ & $\begin{array}{c}0.3747 \\
(1.50)\end{array}$ & $\begin{array}{c}0.1997 * \\
(1.75)\end{array}$ & $\begin{array}{c}0.2018 \\
(1.29)\end{array}$ & $\begin{array}{c}0.2032 * \\
(1.90)\end{array}$ & $\begin{array}{c}0.3267 * * \\
(2.20)\end{array}$ \\
\hline lagvolatilitydw & $\begin{array}{l}-0.0611 \\
(-0.77)\end{array}$ & $\begin{array}{c}-0.0384 \\
(-0.38)\end{array}$ & $\begin{array}{l}-0.0494 \\
(-0.75)\end{array}$ & $\begin{array}{c}-0.2123 * * \\
(-2.09)\end{array}$ & $\begin{array}{l}-0.0173 \\
(-0.30)\end{array}$ & $\begin{array}{l}-0.1214 \\
(-1.44)\end{array}$ \\
\hline $\operatorname{lagMBw}$ & $\begin{array}{c}-0.0254 \\
(-1.56)\end{array}$ & $\begin{array}{c}0.0574 * * \\
(2.52)\end{array}$ & $\begin{array}{c}0.0013 \\
(0.10)\end{array}$ & $\begin{array}{c}0.1055^{* * * *} \\
(3.91)\end{array}$ & $\begin{array}{c}0.0049 \\
(0.43)\end{array}$ & $\begin{array}{c}0.1084 * * * \\
\quad(5.20)\end{array}$ \\
\hline Constant & $\begin{array}{c}5.0319 * * * \\
(31.44)\end{array}$ & $\begin{array}{c}4.6014 * * * \\
(17.08)\end{array}$ & $\begin{array}{c}6.5163 * * * \\
(22.15)\end{array}$ & $\begin{array}{c}6.8529 * * * \\
(16.79)\end{array}$ & $\begin{array}{c}5.0298 * * * \\
(38.10)\end{array}$ & $\begin{array}{c}4.9052 * * * \\
(30.25)\end{array}$ \\
\hline Observations & 8,553 & 8,544 & 8,553 & 8,544 & 8,553 & 8,544 \\
\hline R-squared & 0.444 & 0.490 & 0.170 & 0.142 & 0.158 & 0.132 \\
\hline Number of firms & 1,465 & 1,465 & 1,456 & 1,456 & 1,456 & 1,456 \\
\hline
\end{tabular}

Robust t-statistics in parentheses

$* * * \mathrm{p}<0.01, * * \mathrm{p}<0.05, * \mathrm{p}<0.1$ 
The first two columns present results of ordinary least squares (OLS) regressions with industry and year fixed effects. The findings show a negative and significant relationship (at 5\% and 10\% level) between CSR and executive compensation (cash and total compensation). These primary results are consistent with hypothesis 4. Further, maintaining high consistency in CSR has no impact on cash and total compensation. In this respect, both coefficients of temporal CONS are insignificant (e.g. t-statistic of 0.77 for cash compensation). There is also evidence suggesting a neutral impact of the interaction between temporal CONS and the level of CSR.

We check the robustness of these primary findings in several ways. First, we rely on firm-fixed effects (FE) estimations to account for time-invariant firm characteristics (column (3) and (4) in table (2)). The inclusion of FE test does alter the association between CSR and CEO compensation. Indeed, both coefficients of CSR become insignificant suggesting a neutral relationship between CSR and executive compensation. On the other hand, the coefficients associated with temporal CONS and the interaction between CSR and temporal CONS remain non significant. We also run regression (1) using random effects (RE) estimations. Column (5) and (6) of table (2) present the findings of this additional test. Again, the association between CSR and CEO compensation is insignificant. Further, the results presented in column (5) and (6) show that temporal CONS and the interaction between CSR and temporal CONS have a neutral effect on CEO compensation. The findings of FE and RE estimations are consistent with hypothesis 2. 
Table 3 :

CSR and Interdomain CONS

VARIABLES

\begin{tabular}{|c|c|c|c|c|c|c|}
\hline $\operatorname{lagCSR}$ & $\begin{array}{c}-1.0567 * * * \\
(-4.40)\end{array}$ & $\begin{array}{c}-1.5159 * * * \\
(-5.23)\end{array}$ & $\begin{array}{c}-0.3708 * \\
(-1.89)\end{array}$ & $\begin{array}{c}-0.0753 \\
(-0.31)\end{array}$ & $\begin{array}{c}-0.5103 * * * \\
(-2.72)\end{array}$ & $\begin{array}{c}-0.3633^{*} \\
(-1.69)\end{array}$ \\
\hline \multirow[t]{2}{*}{ Lag INTERD-CONS } & -0.0678 & $-0.2920 * * *$ & -0.0666 & -0.0459 & -0.0211 & -0.0266 \\
\hline & $(-0.75)$ & $(-2.59)$ & $(-0.88)$ & $(-0.50)$ & $(-0.29)$ & $(-0.30)$ \\
\hline \multirow[t]{2}{*}{ Lag CSR * INTERD-CONS } & $2.3762 * * *$ & $4.0195 * * *$ & 0.2595 & -0.4157 & 0.7097 & 0.5614 \\
\hline & $(3.25)$ & $(4.63)$ & $(0.48)$ & $(-0.61)$ & $(1.35)$ & $(0.89)$ \\
\hline \multirow[t]{2}{*}{ lagtenure_cum } & 0.0010 & -0.0017 & $0.0076 * * *$ & 0.0033 & 0.0037 & 0.0009 \\
\hline & $(0.32)$ & $(-0.48)$ & $(2.70)$ & $(0.93)$ & $(1.50)$ & $(0.31)$ \\
\hline \multirow[t]{2}{*}{ Lagage } & $0.0046 * * *$ & -0.0017 & -0.0013 & -0.0015 & 0.0009 & -0.0019 \\
\hline & $(2.75)$ & $(-0.92)$ & $(-0.73)$ & $(-0.80)$ & $(0.63)$ & $(-1.24)$ \\
\hline \multirow[t]{2}{*}{ Lagsizew } & $0.2448 * * *$ & $0.4722 * * *$ & $0.0705^{* * *} *$ & $0.2489 * * *$ & $0.1997 * * *$ & $0.4222 * * *$ \\
\hline & $(25.31)$ & (35.92) & $(3.56)$ & (9.99) & $(21.75)$ & $(37.87)$ \\
\hline \multirow[t]{2}{*}{ lagbleveragew } & 0.0232 & -0.0198 & $-0.1220 * * *$ & $-0.2211 * * *$ & -0.0268 & $-0.1064 * * *$ \\
\hline & $(0.57)$ & $(-0.40)$ & $(-3.44)$ & $(-5.27)$ & $(-0.87)$ & $(-3.03)$ \\
\hline \multirow[t]{2}{*}{$\operatorname{lagRDw}$} & -0.1564 & $1.2394 * * *$ & 0.5272 & -0.0580 & -0.1878 & $0.6913 * *$ \\
\hline & $(-0.51)$ & (3.18) & (1.14) & $(-0.09)$ & $(-0.73)$ & $(2.15)$ \\
\hline \multirow[t]{2}{*}{ Lagcapexw } & $-0.4039 * *$ & $-0.4680^{*}$ & $-0.5291 * * *$ & -0.3153 & $-0.3928 * * *$ & $-0.4313 * *$ \\
\hline & $(-1.99)$ & $(-1.81)$ & $(-3.23)$ & $(-1.44)$ & $(-2.76)$ & $(-2.36)$ \\
\hline \multirow[t]{2}{*}{ lagROAw } & $0.6683 * * *$ & $0.4651 * *$ & $0.3286^{* *}$ & $0.4156^{* * *}$ & $0.4809 * * *$ & $0.4581 * * *$ \\
\hline & (4.22) & $(2.47)$ & $(2.30)$ & $(2.59)$ & $(3.76)$ & $(3.21)$ \\
\hline \multirow[t]{2}{*}{ lags_cashw } & $0.2478 *$ & $0.4755^{* *}$ & $0.2763 * *$ & 0.1531 & $0.2483 * *$ & $0.2330 *$ \\
\hline & $(1.77)$ & $(2.45)$ & $(2.57)$ & (1.15) & $(2.45)$ & (1.84) \\
\hline \multirow[t]{2}{*}{ lagvolatilitydw } & $-0.1549 * *$ & 0.0559 & $-0.1865 * * *$ & -0.0793 & $-0.1889 * * *$ & -0.0341 \\
\hline & $(-2.47)$ & $(0.71)$ & $(-3.36)$ & $(-1.08)$ & $(-3.70)$ & $(-0.52)$ \\
\hline \multirow[t]{2}{*}{ lagMBw } & $-0.0341 * * *$ & $0.0729 * * *$ & -0.0120 & $0.1036^{* * *}$ & -0.0085 & $0.1099 * * *$ \\
\hline & $(-2.63)$ & (4.34) & $(-1.25)$ & $(6.49)$ & $(-0.95)$ & $(8.14)$ \\
\hline \multirow[t]{2}{*}{ Constant } & $5.0002 * * *$ & $4.3918 * * *$ & $6.3825 * * *$ & $6.4508 * * *$ & $5.1581 * * *$ & $4.9569 * * *$ \\
\hline & (26.38) & (20.19) & (31.89) & $(27.04)$ & (48.96) & (39.54) \\
\hline Observations & 14,295 & 14,251 & 14,295 & 14,251 & 14,295 & 14,251 \\
\hline R-squared & 0.433 & 0.481 & 0.161 & 0.208 & 0.149 & 0.200 \\
\hline Number of firms & 1,923 & 1,923 & 1,923 & 1,921 & 1,923 & 1,921 \\
\hline
\end{tabular}

Random effects totcomp cashcomp totcomp

cashcomp
totcomp cashcomp 
In table (3), our estimates of equation (1) are performed using inter-domain CONS instead of temporal CONS. When we account of inter-domain CONS, the relationship between CSR and cash compensation is negative and significant in all specifications while the relationship between CSR and total compensation is negative and significant in two of three estimations. These additional findings show a strong evidence of a negative association between CSR and CEO compensation, which is consistent with hypothesis (4). On the other hand, Inter-domain CONS and its interaction with CSR have a neutral effect in four of the six estimations presented in table (3). In general, it seems that CSR consistency (temporal and inter-domain) plays an insignificant role in influencing CEO compensation.

So far, our empirical results are consistent with previous research that found an inverse relationship between lagged CSR and CEO compensation (e.g. Cai et al. 2011). However, contrary to previous studies, we argue that the negative CSR/COE pay link is not the result of socially responsible CEOs taking lower pay to resolve conflicts of interests among managers and stakeholders (Cai et al. 2011). In this respect, based on our new perspective (the negative externality hypothesis), the stakeholders' management of talented CEOs should result in excessive CEOs pay while managers who pursue inefficient stakeholders' initiatives should have lower compensation. Hence, in contrast to utilitarian approaches (e.g. strategic or stakeholders' driven CSR), we consider virtue ethics as the main factor that explains the negative association between CSR and CEO compensation. Further, the presence of a negative CSR/CEO pay link does not imply that firms with weak CSR engagement propose less efficient pay packages. 
Table 4.

CSR and Temporal CONS

VARIABLES

$\operatorname{lagCSR}$

Lag TP-CONS

Lag CSR *TP-CONS

lagtenure_cum

Lagage

Lagsizew

lagbleveragew

$\operatorname{lagRDw}$

Lagcapexw

$\operatorname{lagROAw}$

lags_cashw

lagvolatilitydw

$\operatorname{lagMBw}$

Constant

Observations

R-squared

Number of firms

p-value of Hansen J statistic

degrees of freedom

F statistic
Instrumental variables estimation

cashcomp

$-6.7743$

totcomp

$(-1.19)$

(0.24)

$-13.8259$

48.9851

$(-0.29)$

(0.79)

150.1468

(1.00)

$-0.0010$

$-107.8605$

$(-0.57)$

0.0015

$(-0.18)$

$(0.21)$

0.0046

0.0014

(1.60)

(0.36)

0.2781

0.2485

(1.46)

(1.00)

0.0960*

0.0222

(1.68)

(0.29)

0.1082

0.2543

(0.14)

(0.25)

$-0.1344$

0.4661

$(-0.19)$

(0.49)

$0.5233^{* *}$

0.2825

(2.12)

(0.89)

0.1969

0.4874

(0.73)

(1.21)

$-0.1955$

$-0.1692$

$(-1.39)$

(-0.98)

$-0.0162$

0.0310

$(-0.78)$

(1.02)

$4.3206 * * *$

(7.49)

$5.3502 * * *$

(7.08)

7,210

7,202

0.200

0.239

1298

1298

0.489

0.330

69

69

23.78

Robust t-statistics in parentheses

$* * * \mathrm{p}<0.01, * * \mathrm{p}<0.05, * \mathrm{p}<0.1$ 
When we rely on IV estimations to address the endogeneity problem, we find that the coefficient on CSR becomes insignificant in all specifications. For instance, the results presented in table (4) (CSR and temporal CONS) show that CSR engagement has a neutral impact on CEO total compensation, with a coefficient of 1.7231 and a t-statistic of 0.24. Furthermore, the temporal CONS and its interaction with CSR still have a neutral impact on CEO compensation. IV estimations based on inter-domain CONS (see table (5)) also show the presence of a neutral relationship between CSR, CSR consistency and CEO pay. So far, there is strong evidence that CSR consistency is irrelevant to CEO compensation while the empirical evidence on the relationship between CSR and CEO pay is inconclusive. However, the new findings of the endogeneity correction procedure allow further key insights. First, these results indicate that CSR impact on CEO compensation is a complex phenomenon that can't be explained by one theoretical argument. Indeed, the neutral association between CSR and CEO pay is consistent with hypothesis (2) developed from the stakeholders' theory and public interest theory. Second, IV estimation results suggest that government regulation can have a possible moderating effect on the CSR/CEO compensation link (public interest perspective). We recognize that we do not offer a direct empirical approach to test the public interest hypothesis. Our contribution in this area is mostly theoretical. Future research should then propose more robust empirical approaches that will help examine the relevance/irrelevance of the regulatory perspective. Third, the neutral association between CSR and CEO pay should be considered as good news for most market participants because it accords with the prediction that some mechanisms (e.g. regulation) may help internalize the negative externality of CSR investments. Finally, the findings of our IV procedure are not an indicator that firms with low CSR engagement do offer compensation packages that depart from value-maximising outcomes. 
Table 5.

CSR and Interdomain CONS

VARIABLES

$\operatorname{lagCSR}$

Lag INTERD-CONS

Lag CSR* INTERD-CONS

lagtenure_cum

Lagage

Lagsizew

lagbleveragew

$\operatorname{lagRDw}$

Lagcapexw

$\operatorname{lagROAw}$

lags_cashw

lagvolatilitydw

$\operatorname{lagMBw}$

Constant

Observations

R-squared

Number of firms

p-value of Hansen J statistic

degrees of freedom

F statistic
Instrumental variables estimation

cashcomp

$-2.4057$

otcomp

$(-0.76)$

(0.09)

$-2.4283$

$-5.0226$

$(-0.66)$

$(-0.94)$

6.8219

$-2.9377$

(0.83)

$(-0.25)$

$-0.0021$

$-0.0065$

$(-0.40)$

$(-0.85)$

$0.0047 * *$

$-0.0018$

(2.52)

$0.3049 * * *$

(2.68)

0.0068

(0.10)

0.3147

(0.44)

$(-0.71)$

$0.6111^{* * *}$

(3.73)

$-0.0582$

$(-0.61)$

$2.0099 * *$

$-0.3738$

(1.99)

$(-1.02)$

$-0.5681$

$0.7848 * * *$

$(-1.12)$

(3.60)

0.6850 **

0.1718

(2.31)

(1.27)

$0.4086^{* *}$

(1.99)

$-0.1001$

0.1806

$(-0.62)$

(0.82)

$-0.0242$

$(-1.29)$

$4.9458 * * *$

(17.56)

$0.0815^{* * *}$

$5.0984 * * *$

(11.84)

12,501

12,541

0.334

0.367

1752

0.105

0.372

74

74

32.71

Robust t-statistics in parentheses

$* * * \mathrm{p}<0.01, * * \mathrm{p}<0.05, * \mathrm{p}<0.1$

Finally, we perform variant estimations of equation (1) (Pooled, OLS, FE, RE, and IV estimations) for two subsamples: S\&P 500 firms and non S\&P 500 firms. Our main findings remain robust to these additional tests (results are available upon request).

\section{Discussion}

The sharp rise in CEO pay has sparked an intense debate about the presence of inefficiencies in the managerial labor market. Some authors have proposed the managerial power theory to explain why CEO labor markets are inefficient (e.g. Bebchuk \& Fried, 2003). They argue that executive compensation is the result of powerful managers that determine their own pay levels and extract rents from poorly governed firms. According to them, CEOs can capture a large fraction of their firms' rents because of their superior knowledge (asymmetric information problem) and 
acquiescent boards (board "capture" problem). The managerial power theory suggests that executive pay arrangements represent a governance/market failure. Therefore, government intervention is needed to correct this failure and put firms' scarce resources to their highest value. Furthermore, firms can also choose arrangements beyond what is legally required (e.g. CSR engagements) to find efficient solutions to managerial pay issue. In this paper, we propose a new theory that suggests the prevalence of a market failure even in the absence of the principal-agentstakeholder problem. In particular, we argue that the choice of the level of CSR by some firms may influence executive compensation of other firms because of the competition in CEO labor markets. Firms' with strong CSR engagement may impose a negative externality on competitors with weak CSR standards. Due to this externality, firms with poor CSR could offer more generous compensation packages to attract managers with strong stakeholders' management skills. In addition, even if they commit to high CSR standards, firms can choose to pay inefficiently their CEOs in order to retain their talent and make the manager's outside option less valuable. We argue that the greater the competition for managerial talent, the larger the resulting overpayment.

Our new perspective sheds a different light on the potential association between CSR and CEO compensation. It suggests that efficient levels of CSR should be irrelevant for helping firms achieve optimal levels of CEO pay. To date, we are not aware of any study that explains why excessive compensation may arise even if CSR allows firms to solve the agency problem. In addition, the externality view of CSR can also contributes to the debate about whether the implementation of strong CSR standards should be left to markets mechanisms or to regulation. The theoretical framework of this paper suggests that CSR regulation could help internalize the negative externality linked to voluntarily CSR engagements. We argue that regulation can impose a standard and efficient format of CSR for all firms. Because standard CSR rules remove the differential level of CSR between firms, the choice of CSR should not impact the level of CEO pay. Most of the empirical findings (neutral CSR-CEO compensation link) suggest that US policymakers are able to set regulations that help internalize the negative externality proposed in this research and allow CEO compensation to achieve optimal levels. Some of the results are also consistent with previous research that found negative associations between CSR and CEO pay. On the other hand, contrary to previous studies, we argue that virtue ethics is the main factor that explains such relationship. We do not consider the negative CSR-CEO pay link to be consistent with the conflict resolution hypothesis (Stakeholders' theory).

\section{Conclusion}

This study offers a new perspective on the potential impact of CSR on CEO compensation by incorporating the CSR externality view. The latter suggests that researchers should not focus only on the value impact of CSR for shareholders and stakeholders. They should also consider whether CSR investments are value increasing or value decreasing for firms' competitors (inter-firms benefits or costs). We explain that it is possible to witness large and inefficient compensation packages for highly skilled managers even in the absence of the principal-agent-stakeholder problem. The source of the inefficient levels of executive pay is the negative externality that some CEOs impose on firms with weak CSR standards. We also conjecture that it is possible to have a neutral effect of CSR on CEO pay when policymakers work for the public good. Indeed, the presence of a market failure may justify regulatory solutions. We conjecture that if regulators promote the public interest and propose efficient regulations that correct market failures, CSR should have no impact on CEO compensation. However, creating appropriate CSR regulatory standards would require knowledge of the nature and extent of the externality. In this respect, it is possible that regulators do not have sufficient information or the appropriate incentives to better assess the extent of such externality. Therefore, more empirical research is needed in order to investigate whether policymakers are able to set regulations that allow CEO compensation to achieve optimal levels (public interest perspective). It is worth mentioning that our tests do not offer a direct empirical analysis to verify the public interest hypothesis. Future research should also propose potential market-based mechanisms that can enable firms' to internalize the CSR externality. For instance, it will be interesting to examine the role of market corporate control in the form of shareholder activists that have strong incentives to improve CSR. In the presence of independent firms not owned by the same shareholders, we may witness large differences in CSR levels between firms and ultimately inefficient levels of CEO pay. On the other hand, if firms with poor CSR are taken over and their CSR standards improved, it is possible to reduce the underinvestment in CSR by some firms and mitigate the negative externality of CSR choice. 


\section{References}

Aron, J., McMillan, A., \& Dunne T. (2015). Optimal incentive-based compensation contracts for CEOs: the impact of CEO age and tenure. Advances In Business Research, 6, 46-64.

Barnea, A., \& Rubin, A. (2010). Corporate social responsibility as a conflict between shareholders. Journal of Business Ethics 97, 71-86.

Barney, J.B. (2018). Why resource-based theory's model of profit appropriation must incorporate a stakeholder perspective. Strategic Management Journal, 39, 3305-3325.

Bebchuk, L, \& Fried, J. (2003). Executive compensation as an agency problem. Journal of Economic Perspective, 17, 71-92.

Bebchuk, L, \& Jackson, R. (2014). Toward a constitutional review of the poison Pill. Columbia Law Review, 1549-1594.

Bertrand, M., \& Mullainathan, S. (2001). Are CEOs rewarded for luck? The ones without principals are. Quarterly Journal of Economics, $116,901-932$.

Brown, D.A. (1996). The invisibility factor: the limits of public choice theory and public institutions. Washington University Law Quarterly, 76, 179-222.

Cai, Y., Jo, H., \& Pan, C. (2011). Vice or virtue? The impact of corporate social responsibility on executive compensation. Journal of Business Ethics, 104, 159-173.

Cespa, G., \& Cestone, G. (2007). Corporate social responsibility and managerial entrenchment. Journal of Economics and Management Strategy 16, 741-771.

Easterbrook, F. \& Fischel, D. (1984). Mandatory Disclosure and the Protection of Investors. Virginia Law Review, 70.

Faria, P., Martins, F.V., \& Brandao, E. (2014). The level of CEO compensation for the short and long-term: a view on high-tech firms. Procedia Social and Behavioral Sciences, 110, 1023-1032.

Fox, B.M. (1999). Retaining mandatory securities disclosure: why the issuer choice is not investor empowerment, Virginia Law Review, 85, p.1335-1419.

Freeman, T., \& Hasnaoui, A. (2011). The meaning of corporate social responsibility: the vision of four nations. Journal of Business Ethics 100, 419-443.

Gabaix, X, \& Landrier, A. (2008). Why has CEO pay increased so much? The Quarterly Journal of Economics, 123. 49-100.

Harjoto, M., \& Jo, H. (2011). Corporate governance and CSR nexus. Journal of Business Ethics 100, 45-67.

Jensen, M. (2002). Value maximization, stakeholder theory, and the corporate objective function. Business Ethics Quarterly, 12, $235-256$.

Jensen, M., \& Murphy, K. (1990). Performance pay and top management incentives. Journal of Political Economy, 98, 225264.

Jensen, M., Murphy, K., \& Wruck, E.G. (2015). CEO Pay and What to Do About It: Restoring Integrity to Both Executive Compensation and Capital-Market Relations. Harvard Business School Press.

Jo, H., \& Harjoto, M. (2012). The causal effect of corporate governance on corporate social responsibility. Journal of Business Ethics 106, 53-72.

Murphy, K. (1999). Executive compensation. Amsterdam : North Holland.

Murphy, K. (2013). Executive compensation: where we are, and how we got there. Chapter 4 in Handbook of economics of finance.

Petersen, M. A. (2009). Estimating standard errors in finance panel data sets: Comparing approaches. Review of Financial Studies, 22(1), 435-480.

Saphira, A.C., Karen, L.B, \& Robert, W.F. (2014). Corporate social responsibility and CEO compensation revisited: Do disaggregation, market stress, gender matter? Journal of Economics and Business, 72 , 84-103.

Wang, H., \& Choi, J. (2013). A new look at the corporate social-financial performance relationship: the moderating role of temporal and interdomain consistency in corporate social performance. Journal of Management, 39, 416-441.

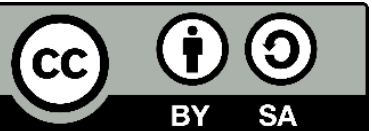

(C) 2020 by the authors. Licensee ACRN Publishing, Austria, Editor in Chief Prof. Dr. Othmar M. Lehner. This article is an open access article distributed under the terms and conditions of the Creative Commons Attribution (CC BY SA) license (https://creativecommons.org/licenses/by-sa/4.0/) 